\title{
From Dry to Wet, 1988-97, North Dakota
}

\section{Introduction}

Unusual climatic and hydrologic conditions continue to affect the people and resources of North Dakota. Above-average precipitation during 1993-97 caused flooding in parts of North Dakota, and damage to crops, roads, and homes led to tremendous economic losses and increased personal stress for the people of the State. However, the above-average precipitation also replenished diminished water supplies, produced bumper crops in some parts of the State, enhanced wildlife and fishery resources, and improved recreational activities such as fishing, camping, and boating. Thus, prolonged periods of above-average precipitation (wet periods) and the resulting hydrologic conditions can be beneficial and prosperous but also can be as disastrous and economically damaging as periods of drought (dry periods).

\section{Climatic and Hydrologic Conditions}

North Dakota is located in a generally semiarid region where climatic and hydrologic conditions can change substantially in a relatively short time. The generally warm, dry conditions that resulted in low runoff during 1988-92 changed to generally cool, wet conditions that resulted in high runoff and flooding during 1993-97. Information on the 1988-92 dry period is given in "Climatic and Hydrologic Aspects of the 1988-92 Drought and the Effect on People and Resources of North Dakota" (Williams-Sether, Tara, MacekRowland, K.M., and Emerson, D.G., 1994, North Dakota State Water Commission Water Resources Investigation 29.57 p.). For comparative purposes, data for the dry period also are included in the figures and tables in this fact sheet.

During 1993-97. total annual precipitation generally was above the long-term average for each of the nine National Climatic Data Center climatic divisions in North Dakota (fig. 1). The departure from average generally was greater in the central and eastern parts of the State than in the western part. Annual precipitation generally was greatest during 1993 when totals were as much as 52 percent above average and least during 1997 when totals were as little as 17 percent below average. Annual average temperatures during 1993-97 ranged from 3.4 degrees Fahrenheit below the average annual to 2.1 degrees Fahrenheit above the average annual (fig. 2).

Runoff in North Dakota depends largely on climatic and soil conditions and can be greater than average one year and below average the next. The warm, dry conditions that resulted in record low flows or no flows in many streams during 1988-92 changed dramatically during 1993-97 (fig. 3). The cool, wet conditions during 1993-97 resulted in peak flows and annual mean flows that generally were much above average in the eastern half of the State. Peak flows at selected gages in the central, east-central, and southeast climatic divisions ranged from 4 percent below average to 411 percent above average, and annual mean flows ranged from 43 to 531 percent above average. Peak flows at selected gages in the north-central and northeast climatic divisions ranged from 92 percent below average to 552 percent above average, and annual mean flows ranged from 85 percent below average to 419 percent above average. The peak flows and annual mean flows were less extreme in the western half of the State. During 1993-97, peak flows at selected gages in the west-central, southwest, and southcentral climatic divisions ranged from 75 percent below average to 256 percent above average, and annual mean flows ranged from
57 percent below average to 237 percent above average.

Large peak flows usually are correlated with large annual mean flows, and small peak flows usually are correlated with small annual mean flows. For example, the 1997 peak flow at the Red River of the North at Grand Forks, N. Dak., gage was ranked $1^{\text {st }}$ (of the peak flows for all the years of record), and annual mean flow was ranked $1^{\text {st }}$ (table 1$)$. Both rankings were within the top 10 percent of years of record. In the 116 years of record for the gage, peak flow for 1990 was ranked $99^{\text {th }}$, and annual mean flow was ranked $98^{\text {th }}$. However, in 1989 , peak flow was ranked $13^{\text {th }}$, and annual mean flow was ranked $52^{\text {nd }}$.

Ground-water levels generally rose during the 1993-97 wet period, and most unconfined aquifers have recovered substantially since the 1988-92 drought because of increased infiltration from above-average precipitation. Ground-water levels in selected wells in the northeast, central, and southwest climatic divisions (fig. 4) reached near-record or record lows in 1991 and 1993 and then rose about 3.5 to 7.0 feet to reach near-record or record highs in 1995. Irrigation wells drilled into confined aquifers also were affected by the wet period. For example, in the east-central

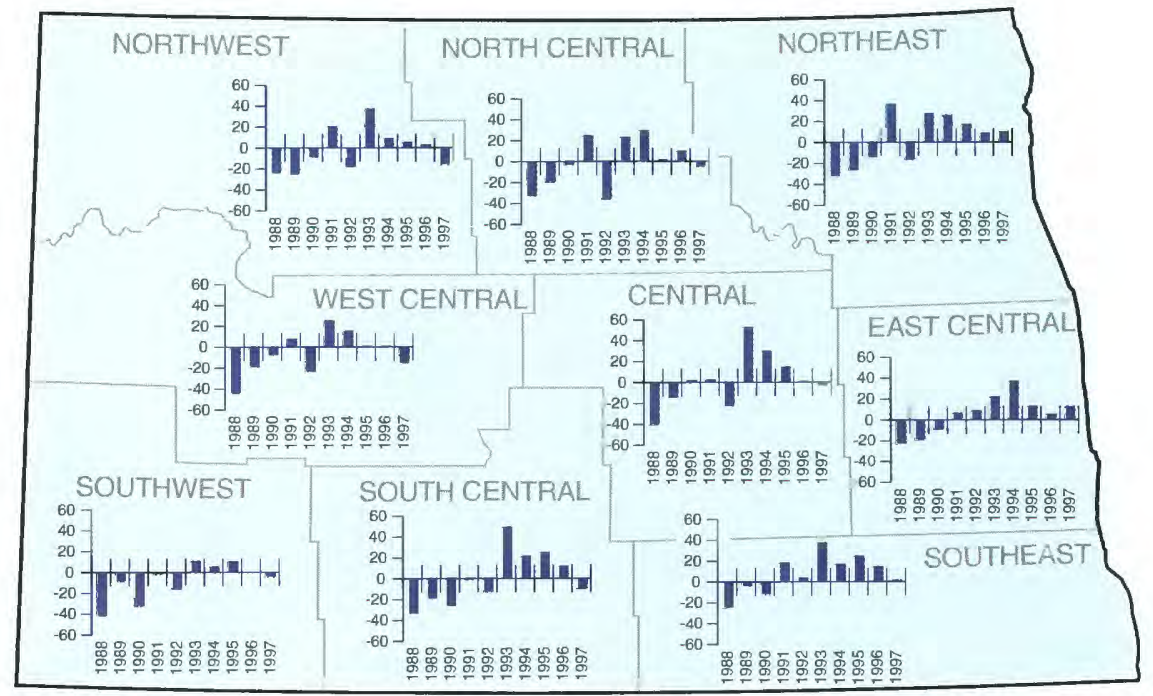

Figure 1. Percentage departure of annual precipitation during 1988-97 from average annual precipitation during 1895-1997. 


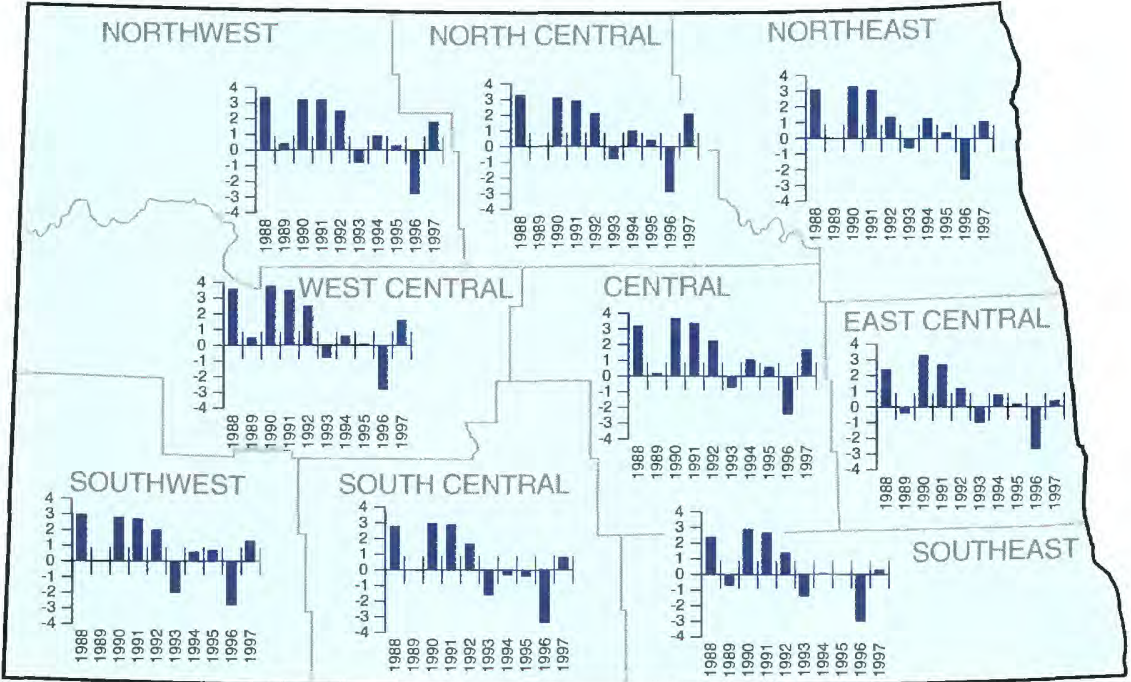

Figure 2. Departure of annual average temperature, in degrees Fahrenheit, during 1988-97 from average annual temperature during 1895-1997. climatic division, water use decreased (reflected in lesser annual water-level fluctuations) when climatic and crop conditions were favorable, especially in 1993, but water levels increased despite pumpage. The increase probably indicates the hydraulic effect of climatic conditions even on confined aquifers.

\section{People and Resources}

The 1993-97 wet period produced mixed effects on agricultural activities throughout the State. At times, the wet conditions delayed or prevented crop planting and harvesting, thus causing poor crop yields. At other times, the wet conditions were timely, thus causing bumper crop yields. As in most years, some crops also were damaged by hail or heavy rainfall resulting from thunderstorms. Wet conditions in the eastern half of the State enhanced the spread of fungi-type diseases that affected primarily small grains and some row crops and provided an ideal environment for the orange wheat-blossom midge that troubled many grain producers. However, wet conditions in the western half of the State caused little crop disease and few insect problems.

Pastureland generally was in good condition during 1993-97. However, livestock were stressed during the very cold, wet conditions of the winters and early springs. Hay crops generally were above average, but, because haying activities were hampered at times because of the wet conditions, some hay crops were of poor quality.

Tremendous damage also occurred to the road systems in North Dakota during 1993-97. About $\$ 119$ million in Federal emergency relief funds for road repairs were issued during that time, and, of the $\$ 119$ million, the Devils Lake Basin (see index map in figure 3) much personal stress also were incurred, especially in the Devils Lake Basin, in fixing and protecting infrastructure, moving homes, and ment and flooding (Roger Hollevoet, U.S. Fish and Wildlife Service, written commun., 1997).

Although the harsh winters and springs of 1993-97 were hard on some wildlife because of limited forage and shelter and hampered reproduction, fish and wildlife in the State generally benefited during that period. Lake levels increased substantially, thus expanding fish and waterfowl habitat and increasing opportunities for fishing, hunting, and trapping. Generally, recreational activities also improved although, in certain areas, campgrounds and boat ramps were flooded and became inaccessible.

\section{Comparison of the 1993-97 Wet Period to Past Wet Periods}

The 1993-97 wet period was unusual because of the large area affected by excess water. Past wet periods in North Dakota generally were restricted to isolated areas, but the 1993-97 providing solutions for watershed manage-
Federal Highway Administration, written commun., 1998). Large financial losses and
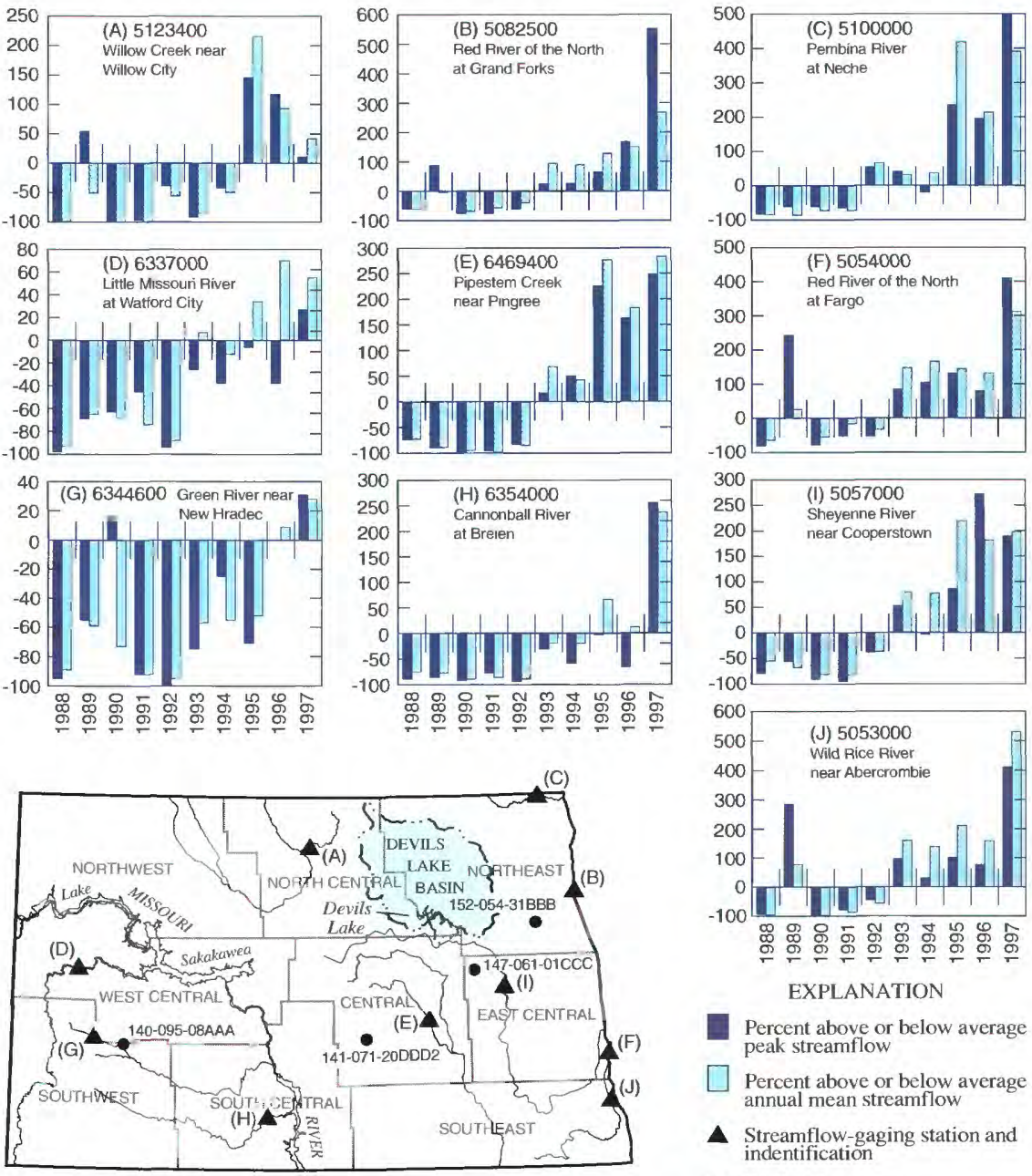

Percent above or below average peak streamflow

$\square$ Percent above or below average annual mean streamflow

A Streamflow-gaging station and indentification
- Well and number

Figure 3. Percent above and below average peak and annual mean streamflow at selected gages. 
Table 1. Ranks of peak flow and annual mean flow at selected gages during 1988-97

[Numbers indicate rank; shaded numbers indicate rank is in top 10 percent of years of record]

\begin{tabular}{|c|c|c|c|c|c|c|c|c|c|c|c|c|}
\hline Station number and name & $\begin{array}{l}\text { Climatic } \\
\text { division }\end{array}$ & 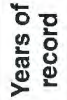 & $\begin{array}{l}\infty \\
\stackrel{\infty}{\sigma}\end{array}$ & : & ஓ & Б & ๙ั & \%్ & 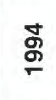 & 吕 & \& & ફे \\
\hline 05123400 Willow Creek near Willow City, N. Dak. & North central & 41 & & & & & & & & & & \\
\hline 05082500 Red River of the North at Grand Forks, N. Dak. & Northeast & 116 & & & & & & & & & & \\
\hline 05100000 Pembina River at Neche, N. Dak. & Northeast & 90 & & & & & & & & & & \\
\hline 06337000 Little Missouri River at Watford City, N. Dak. & West central & 63 & & & & & & & & & & \\
\hline 06469400 Pipestem Creek near Pingree, N. Dak. & Central & 24 & & & & & & & & & & \\
\hline 05054000 Red River of the North at Fargo, N. Dak. & East central & 98 & & & & & & & & & & \\
\hline 05057000 Sheyenne River near Cooperstown, N. Dak. & East central & 53 & & & & & & & & & & \\
\hline 06344600 Green River near New Hradec, N. Dak. & Southwest & 34 & & & & & & & & & & \\
\hline 06354000 Cannonball River at Breien, N. Dak. & South central & 63 & & & & & & & & & & \\
\hline 05053000 Wild Rice River near Abercrombie, N. Dak. & Southeast & 65 & & & & & & & & & & \\
\hline
\end{tabular}

Rank of peak flow

Rank of annual mean flow

wet period generally affected the entire State. However, the southwestern part of the State was affected to a much lesser degree than the remainder of the State. Wet periods of that extent have not occurred since the late 1890's and early 1900's. The Palmer Drought

Severity Index (PDSI; Palmer, W.C., 1965, Meteorological drought: U.S. Weather Bureau Research Paper No. 45, 58 p.) is an index that takes into account precipitation, evapotranspiration, and soil-moisture conditions to determine hydrologic wet and dry periods. The PDSI is readily available and standardized to facilitate direct comparisons between regions. Indexes for the northeast, central, and southwest climatic divisions (fig. 5) were chosen to illustrate an approximate transect across the State from the wettest to driest areas. Indexes for the six climatic divisions that were not chosen follow trends and variability similar to those in the divisions that were chosen. The PDSI, averaged for each year for the three selected climatic divisions across the State, shows several times when the entire State was in a wet period. The magnitude of the wet periods varies with time and between divisions. The percentage of time the wet periods were extreme (PDSI greater than or equal to 4) for the three selected climatic divisions is listed in table 2. During 1993-97, the northeast division was in the extreme category 62 percent of the time, and the central division was in the extreme category
60 percent of the time. The southwest division was in the extreme category only 5 percent of the time. In contrast, during 1970-73, the southwest division was in the extreme category 40 percent of the time, and the northeast and central divisions were not in the extreme category.

The volume of flow that occurs in given time periods also can be used to compare wet periods. A 5-year running average of the annual mean flows for the Red River of the North at Grand Forks, N. Dak., showed that the total volume of flow was largest (ranked $1^{\text {st }}$ ) during 1993-97 and moderate during 1969-73 (table 3). In contrast, the 5-year running average of the annual mean flows for the Green River near New Hradec, N. Dak., showed that the total volume of flow was relatively low during 1993-97 and largest during 1969-73.

Table 2. Percentage of months in selected time periods that the Palmer Drought Severity Index is greater than or equal to 4 for the northeast, central, and southwest climatic divisions

\begin{tabular}{|l|c|c|c|c|c|c|}
\hline \multicolumn{1}{|c|}{ Climatic division } & $\mathbf{1 8 9 5 - 9 7}$ & $\mathbf{1 9 0 0 - 0 9}$ & $\mathbf{1 9 2 6 - 2 9}$ & $\mathbf{1 9 4 1 - 4 5}$ & $\mathbf{1 9 7 0 - 7 3}$ & $\mathbf{1 9 9 3 - 9 7}$ \\
\hline Northeast & 42 & 45 & 38 & 28 & 0 & 62 \\
\hline Central & 47 & 48 & 12 & 22 & 0 & 60 \\
\hline Southwest & 33 & 10 & 21 & 23 & 40 & 5 \\
\hline
\end{tabular}

Lake levels are excellent indicators of wet and dry periods provided human influence is not too great. On July 26, 1997, Devils Lake (a terminal lake in a closed basin) reached a lake level of 1,443.0 feet above sea level, about 20.4 feet higher than the lake level recorded in February 1993 and the highest lake level in about 170 years (Wiche, G.J., Lent, R.M., Rannie, W.F., and Vecchia, A.V., 1997, A history of lake-level fluctuations for Devils Lake, North Dakota, since the early 1800's: Proceedings of the North Dakota Academy of Science 89th Annual Meeting, v. 51, Grand Forks, North Dakota, April 24-25, 1997. p. 34-39). Above-average precipitation during 1993-97 caused the lake level of Devils Lake to rise rapidly, and about 55,500 acres of land around the lake were flooded. Total estimated inflow to Devils Lake during 1993-97 was about 1.7 million acre-feet or about 40 percent of the total estimated inflow (about 4.3 million acre-feet) during 1950-97. Lake Sakakawea, although largely regulated, also was affected. 
After reaching a minimum lake level of 1,815.0 feet above sea level on May 14. 1991, the lowest level since the lake reached a normal maximum operating level of 1,850.0 feet in 1969 , the lake eventually rose to $1,854.4$ feet above sea level on July 1, 1997. The July 1, 1997, lake level was the second highest lake level since the 1950's and was caused

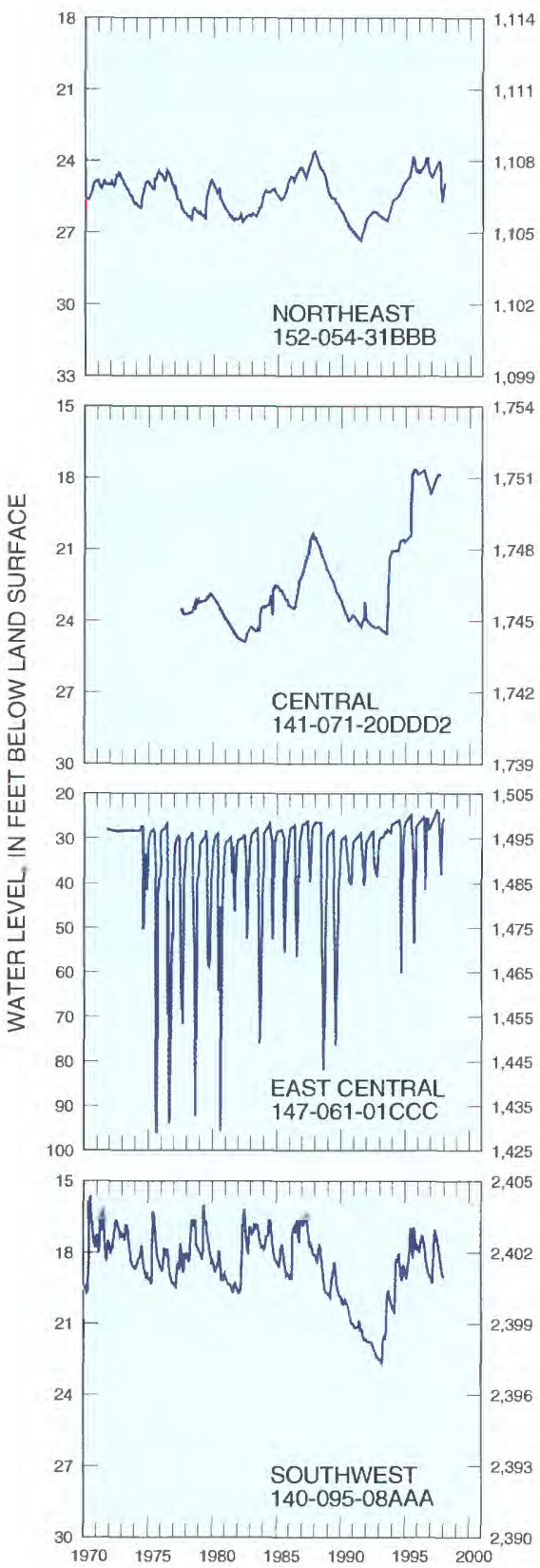

Figure 4. Ground-water levels in selected wells (see index map in figure 3 ) during 1970-97 for northeast, central, east-central, and southwest climatic divisions. largely by runoff from a much-above-average snowpack upstream. During 1997, many record flows were recorded in the State, especially in the Red River of the North Basin. For example, on April 18, 1997, peak flow at the Red River of the North at Grand Forks.
N. Dak., gage, reached a record of 137.000 cubic feet per second. The annual mean flow for 1997 at that gage reached a record of about 10,100 cubic feet per second.

-Tara Williams-Sether

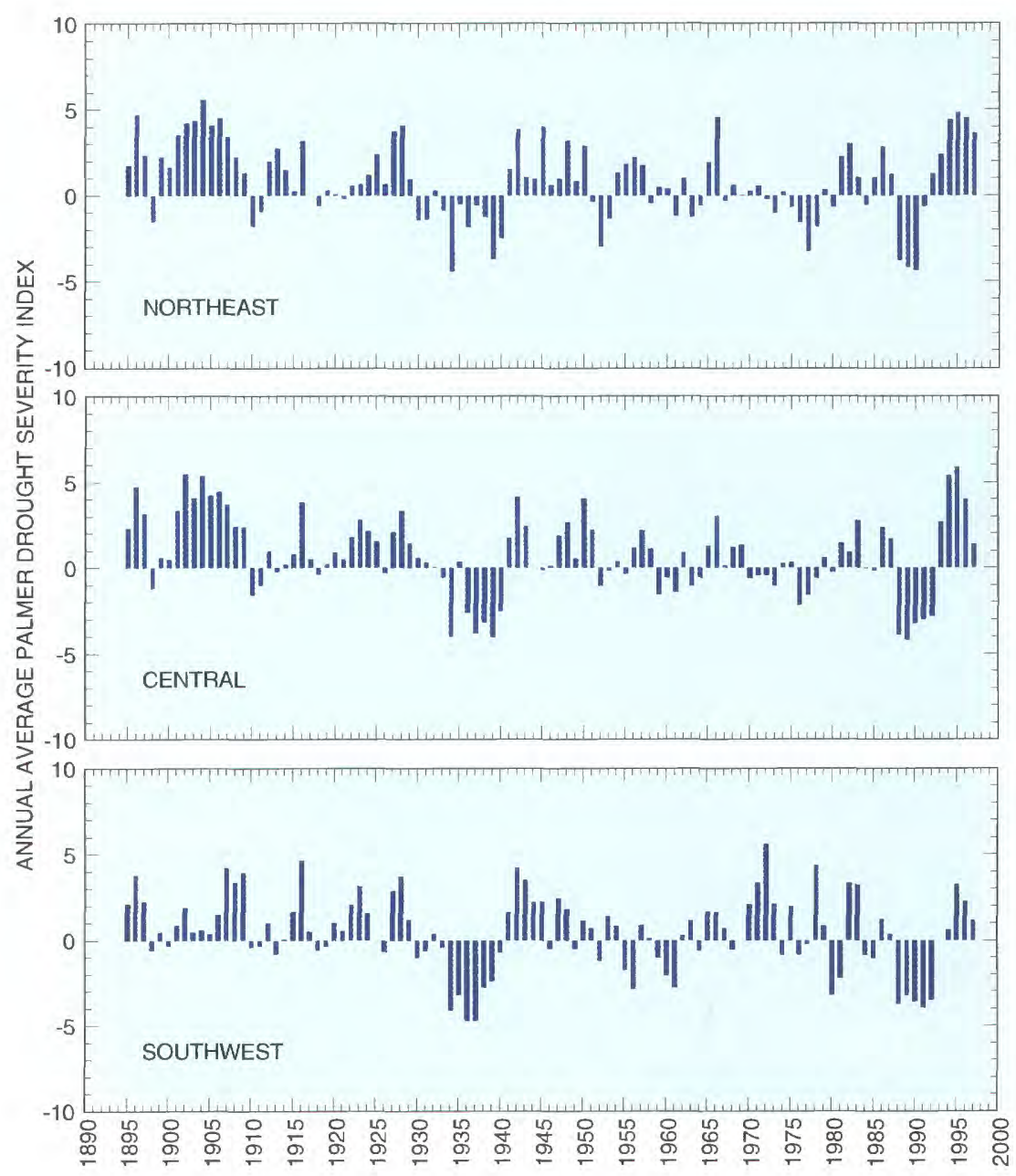

Figure 5. Annual average Palmer Drought Severity Index for the northeast, central, and southwest climatic divisions.

Table 3. Rank of 5-year running average of annual mean flows at selected gages during selected time periods

$[-$, not available $]$

\begin{tabular}{|c|c|c|c|c|c|}
\hline Station number and name & $\begin{array}{c}\text { Climatic } \\
\text { division }\end{array}$ & $\begin{array}{c}\text { Number } \\
\text { of 5-year } \\
\text { periods in } \\
\text { record }\end{array}$ & $\mathbf{1 8 9 3 - 9 7}$ & $\mathbf{1 9 6 9 - 7 3}$ & $\mathbf{1 9 9 3 - 9 7}$ \\
\hline $\begin{array}{c}\text { 05082500 Red River of the North } \\
\text { at Grand Forks. N. Dak. }\end{array}$ & Northeast & 111 & 40 & 26 & 1 \\
\hline $\begin{array}{c}\text { 06344600 Green River near } \\
\text { New Hradec. N. Dak. }\end{array}$ & Southwest & 29 & - & 1 & 23 \\
\hline
\end{tabular}

\section{For more information contact any of the following:}

For water information:

District Chief

821 East Interstate Avenue

Bismarck, ND 5850

(701) $250-7400$
For more information on all USGS reports and products (including maps, images, and computerized data), call 1-800-USA-MAPS.
Additional earth science information can be found by accessing the USGS

"Home Page" on the World Wide Web at

"http://www.usgs.gov". 